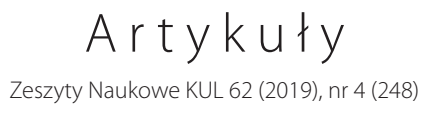

DOI: 10.31743/zn.2019.62.4.01

\title{
Godność ludzka jako wartość i sposoby jej uzasadniania w opinii młodzieży
}

$\checkmark$ odność osobowa w sensie ontologicznym przysługuje każdemu człowiekowi niowalna i absolutna. Ma swoją podstawę w ontycznej strukturze człowieka, dlatego jest niezależna od kontekstu historycznego i społecznego. Posiada ją zatem każdy człowiek, niezależnie od przynależności do danego narodu, klasy, rasy, religii, wykształcenia i zawodu. Zmienia się jedynie nasza świadomość istnienia tej godności oraz konkretne wyrazy jej respektowania. Człowiek jako byt osobowy, a więc rozumny i wolny, jest źródłem własnego działania przez akty decyzyjne, jest obdarzony sumieniem, zdolnością do rozpoznawania dobra i zła oraz odpowiedzialnością. Godność osoby ludzkiej nie jest stopniowalna, podobnie jak i sama osoba. Albo jest się osobą z przyrodzoną godnością, albo się nią nie jest - nie można być osobą w połowie lub częściowo ${ }^{1}$.

Człowiek jako byt psychosomatyczny i społeczny poszukuje wartości. Istnieją wartości zmienne, zależne od sytuacji społeczno-kulturowej i od swobodnej decyzji czy spontanicznego odczucia jednostek, ale są także wartości trwałe, obiektywne i uniwersalne, których istotę i funkcje normatywne wyznacza godność osoby ludzkiej, a nie sytuacja społeczno-kulturowa czy opinia publiczna. Z godności osoby ludzkiej wynikają wartości podstawowe i prawa człowieka:

\footnotetext{
Ks. PROF. DR HAB. JANUSz MARIAŃSKi - Wyższa Szkoła Nauk Społecznych z siedzibą w Lublinie, e-mail: januszm@kul.lublin.pl, ORCID: 0000-0002-0620-8000.

1 A. Lekka-Kowalik, Godność podmiotów edukacji, w: Encyklopedia aksjologii pedagogicznej, red. K. Chałas, A. Maj, Radom 2016, s. 383-384.
} 
równość, solidarność, demokracja, tolerancja, sprawiedliwość społeczna, życie ludzkie, wolny rozwój osobowościowy, pokój, dialog, praca, środowisko naturalne itp. Godność osoby ludzkiej jest zatem fundamentalną wartością całego porządku moralnego (godność własna i godność drugiego człowieka). Obejmuje ona to wszystko, co jest właściwe człowiekowi, jest fundamentalną i centralną normą moralności².

Człowiek jako osoba nie może być traktowany jako zwykły przedmiot czyjejś przyjemności, korzyści czy wygody. Godność osoby jest podstawą równości wszystkich ludzi, przysługuje każdemu człowiekowi w jednakowym stopniu. Człowiekowi przysługuje z jednej strony cecha niepowtarzalnej indywidualności, z drugiej - społecznej natury, która determinuje współdziałanie z innymi osobami dla realizacji wspólnych celów. Jest on również istotą dynamiczną, zdolną do wielowymiarowego rozwoju poprzez zaspokajanie potrzeb materialnych, intelektualnych i duchowych ${ }^{3}$.

We współczesnym świecie wzrasta świadomość niezwykłej godności, jaka przysługuje każdej osobie ludzkiej. Z tej godności wypływają prawa i obowiązki, które mają charakter powszechny i niezbywalny ${ }^{4}$. W Karcie Praw Podstawowych Unii Europejskiej z 2012 roku podkreśla się, że godność człowieka jest nienaruszalna, musi być szanowana i chroniona. Każdy człowiek ma prawo do życia, nikt nie może być skazany na karę śmierci ani poddany jej wykonaniu. Każdy ma prawo do poszanowania jego integralności fizycznej i psychicznej (art. 1, 2, 3). Osoba ludzka nie może wyzbyć się swej ontycznej struktury.

W koncepcji nienormatywnej (opisowej) człowiek nabywa godność w różnym stopniu przez wychowanie w środowiskach społecznych, w różnych kulturach i cywilizacjach oraz przez własną pracę nad swoim rozwojem osobowym (godność osobowościowa). Może ją także utracić przez niemoralne postępowanie lub pod wpływem niekorzystnych czynników zewnętrznych. Wymienia się jeszcze godność osobistą (poczucie godności), niekiedy utożsamianą z honorem, oraz godność społeczną związaną z zajmowaną pozycją czy funkcją w społeczeństwie. Godność osobista oznacza poczucie własnej godności, poczucie czy świadomość własnej wartości i wyraża się w szacunku do samego siebie ${ }^{5}$. Kształtowanie własnej godności i pewności siebie jest równoznaczne z odkrywaniem własnego „ja”. Poczucie godności nie jest trwałym konstruktem przypisanym jednostce na stałe. Wybrany kierunek rozwoju czy postawa wobec rzeczywistości

2 F.J. Mazurek, Wartości akceptowane w Unii Europejskiej, „Summarium” 1999-2000, nr 28-29, s. $11-37$.

3 S. Fel, Społeczna gospodarka rynkowa w społecznej nauce Kościoła katolickiego, w: Socjologia ekonomiczna, red. W. Morawski, Warszawa 2018, s. 160.

4 M. Chymuk, Aksjologiczne preferencje studentów uczelni krakowskich, Kraków 2004, s. 45.

5 B. Kanclerz, Orientacje życiowe młodzieży akademickiej, Poznań 2015, s. 161-162. 
społecznej nie musi być kontynuowany przez całe życie. Jednostka określa go przez ustawiczne wybory.

Godność osobowa wydaje się wartością oczywistą - każdy intuicyjnie wie, czym ona jest. Jeżeli nawet istnieje daleko idąca zgodność co do tego, że godność przysługuje każdemu człowiekowi, to jednak istnieją spory co do tego, kto jest osobą ludzką, jakie są źródła godności ludzkiej i sposoby jej uzasadniania. Różne są też sposoby rozumienia godności ludzkiej, zarówno na płaszczyźnie godności osobowej, jak i osobowościowej oraz osobistej. W niniejszych rozważaniach analizujemy godność ludzką z socjologicznego punktu widzenia. Ujmujemy to zagadnienie moralne jakby „od dołu”, tzn. od strony świadomości młodzieży polskiej, zarówno w aspekcie teoretycznym, jak i empirycznym.

Podstawą do rozważań empirycznych są wyniki badań jakościowych zrealizowanych w latach 2017-2018 wśród różnych kategorii młodzieży uczącej się lub studiującej. Badania socjologiczne przeprowadzono zasadniczo w trzech środowiskach akademickich: Wyższej Szkoły Nauk Społecznych z siedzibą w Lublinie (studenci socjologii, psychologii i pracy socjalnej), Katolickiego Uniwersytetu Lubelskiego Jana Pawła II (studenci pedagogiki) i Uniwersytetu Warmińsko-Mazurskiego w Olsztynie (studenci Wydziału Bioinżynierii Zwierząt i Wydziału Nauk Społecznych) oraz wśród młodzieży szkół średnich w Stalowej Woli. W sumie zebrano 165 mniej lub bardziej obszernych wypowiedzi (65\% kobiet i 35\% mężczyzn). Badania ankietowe na moją prośbę przeprowadzili doktoranci z Instytutu Pedagogiki KUL oraz dr hab. Agnieszka Zduniak z Uniwersytetu Warmińsko-Mazurskiego w Olsztynie.

Respondenci odpowiadali na pięć następujących pytań, z zachętą do udzielenia dłuższych wypowiedzi: 1) Czym według Ciebie jest godność ludzka (godność człowieka)? Jak można ją opisać? Czy w ogóle zastanawiałeś(aś) się nad tym problemem?; 2) Jeżeli uznajesz godność ludzką za wartość, to jak można ją uzasadnić?; 3) Jak oceniasz ludzi o wysokim poczuciu godności własnej?; 4) Czy w swoim życiu lub twoich bliskich przeżyłeś(aś) coś, co można nazwać naruszeniem godności człowieka (opisz tę sytuację)?; 5) Z jakimi przejawami naruszania godności ludzkiej spotykamy się w życiu społecznym w naszym kraju po 1989 roku?; 6) Jaką rolę mogą lub powinny odgrywać wartości godnościowe w wychowaniu młodego pokolenia Polaków?

Najszerzej wypowiadano się na tematy związane $\mathrm{z}$ naruszeniem godności człowieka, zarówno we własnym życiu, jak i w życiu społecznym naszego kraju. Wszystkie zapisane wypowiedzi respondentów zostały uwzględnione w opracowaniu wyników badań. Pochodzą one od studentów I i II roku studiów licencjackich oraz młodzieży z ostatnich klas szkoły średniej. W interpretacji zebranych danych empirycznych, które nie mają charakteru reprezentatywnego, próbujemy ustalić jedynie typowe postawy ludzi wobec godności, sposoby jej uzasadniania, przejawy naruszania godności w różnych sytuacjach życiowych 
oraz proponowane przez badanych metody wychowania do wartości godnościowych. W analizach empirycznych zostały uwzględnione w szerokim zakresie wypowiedzi młodzieży akademickiej, głównie z kierunków humanistycznych.

W niniejszym artykule zwrócimy uwagę tylko na sposoby uzasadniania godności człowieka (przyrodzone i nadprzyrodzone). Rozważania teoretyczne będą przeplatać się z analizą wypowiedzi młodzieży szkolnej i akademickiej na temat godności człowieka. Usiłujemy w tych analizach odpowiedzieć na jedno pytanie, a mianowicie, jak badani uzasadniają tezę o godności człowieka, do jakich argumentów odwołują się, gdy pytamy ich o podstawy aprobaty godności ludzkiej. Przeprowadzone badania empiryczne posiadają wiele ograniczeń (np. mała zbiorowość badanych, przewaga studentów z kierunków pedagogicznych), mimo tego dostarczają jednak pewnej wiedzy o charakterze teoretycznym i praktycznym. Rozważania empiryczne poprzedzimy krótką refleksją na temat źródeł i wymiarów ludzkiej godności jako wartości. Wśród różnych odmian uzasadnień niepodważalny pozostaje aksjomat, że osoba ludzka w swej godności domaga się szacunku bezwarunkowego (absolutnego), niezależnie od wszelkiego dowolnego wartościowania i celowości. Szacunek ten oznacza bezwarunkową godność prowadzenia i chronienia każdego ludzkiego bytu jako tej rzeczywistości, którą nie można dowolnie dysponować.

\section{1. Źródła i wymiary godności ludzkiej - analiza teoretyczna}

Osoba ludzka jest i powinna być zasadą, podmiotem i celem wszystkich urządzeń społecznych (KDK 25). Jest ona istotą samoistną i odpowiedzialną, która w wolnym wyborze sumienia opowiada się za dobrem i unika zła. Osobie ludzkiej przysługuje godność, która polega na tym, że jako osobowy obraz Boga posiada ona własną i niepowtarzalną wartość, której żadna instancja nie jest w stanie jej pozbawić. Każdy pojedynczy człowiek jest celem samym w sobie, a nie środkiem do jakiegokolwiek celu społecznego. Dzięki chrześcijaństwu pojawiło się pojęcie osoby specyfikujące człowieka, odnoszone do niepowtarzalności i indywidualności ludzkiej ${ }^{6}$. Człowiek jako osoba nie jest czymś zapożyczonym od społeczeństwa czy swoistym darem społeczeństwa. Osoba ma charakter pierwotny, na niej wszystko inne się opiera.

To właśnie ujęcie człowieka jako osoby jest punktem wyjścia dla mówienia o ludzkiej godności. Jako osoba człowiek charakteryzuje się posiadaniem siebie, dysponowaniem sobą, nieprzekazywalną odpowiedzialnością za siebie samego.

${ }_{6}$ M. Vidal, Absolutna wartość osoby miejscem spotkania i zespolenia etyki świeckiej z moralnościa religijna, tłum. L. Balter, w: Moralność chrześcijańska, red. L. Balter, K. Czulak, P. Góralczyk, S. Stancel, Poznań-Warszawa 1987, s. 143. 
W praktyce oznacza to, że nie może być zawłaszczony przez żadną instytucję, nie może być przez inne osoby czy instytucje wykorzystywany, ponieważ sam dla siebie jest celem zasadniczym. Mówi się w związku z tym o niepowtarzalnej wartości każdego człowieka. Nie może być on przez nikogo reprezentowany na płaszczyźnie moralnej, lecz odpowiada sam za siebie. Tylko w odniesieniu do człowieka można mówić o tak rozumianej godności. Uzasadnienie tej najważniejszej i niepowtarzalnej wartości osoby i jej godności przebiega nie tylko na płaszczyźnie przyrodzonej, ale przede wszystkim na płaszczyźnie nadprzyrodzonej. O niepowtarzalnej wartości człowieka świadczy nie tylko świadomość, wolność i odpowiedzialność, ale przede wszystkim pochodzenie człowieka od Boga, a także dokonane dla człowieka dzieło Wcielenia i Odkupienia.

Godność osobowa jest wartością pierwotną i wrodzoną, przysługującą każdemu człowiekowi, trwałą i powszechną, niezbywalną i równocześnie zobowiązującą. Wyraża się w tym, że człowiek jest istotą rozumną, wolną i wyposażoną $\mathrm{w}$ sumienie. Zajmuje on $\mathrm{z}$ racji swej godności szczególne miejsce $\mathrm{w}$ świecie. Godność osobowa (ontyczna) jest podstawą i praźródłem przysługujących ludziom prerogatyw, jest wyznacznikiem absolutnej i integralnej koncepcji praw człowieka. Jej trwałość przejawia się w tym, że człowiek nie może się jej nigdy wyzbyć. W swym podstawowym znaczeniu godność ludzka nie dopuszcza żadnych przywilejów, jest etycznym a priori wspólnym dla wszystkich ludzi. Godność ta stanowi jakość ontyczną i aksjologiczną, która nie dopuszcza „więcej” lub „mniej”. W ujęciu teologicznym i filozoficznym godność wiąże się z samą osobą ludzką.

Tadeusz Biesaga - w nawiązaniu do prac niemieckiego etyka Josefa Seiferta - omawia cztery wymiary godności ludzkiej:

a) Godność ontologiczna, którą posiadamy wraz z zaistnieniem natury ludzkiej. Ontologiczna godność osoby przynależy wszystkim istniejącym ludziom, niezależnie od tego, czy są aktualnie świadomi, zdrowi czy chorzy, urodzeni czy rozwijający się w okresie prenatalnym. Godność ta wyklucza urzeczowienie osoby, utylitarne jej traktowanie, jest podstawą prawa do życia i rozwoju. Nie jest ona nadawana człowiekowi, lecz zastana wraz z jego zaistnieniem i jego naturą, jest przynależna mu aż do śmierci. Godność ta nie jest stopniowalna, wszyscy ludzie jako osoby posiadają ją w równym stopniu, nie może być ona stanowiona na zasadzie konsensu, kontraktu czy arbitralnej legislacji. Godność ontologiczna w czasie naszego życia jest niezmienna i nie podlega destrukcji.

b) Godność świadomego podmiotu wynikająca $z$ aktualnie używanej świadomości. Ujawnia się ona w świadomej aktualizacji racjonalności, wolności i miłości, ukazując w intencjonalnych aktach poznania, w języku, wiedzy, w świadomym i odpowiedzialnym odnoszeniu się do innych osób, świata i Boga,

\footnotetext{
Tamże, s. 139.
} 
nasze życie osobowe. Godność aktualnie świadomego podmiotu nie posiada cech stałości i niezmienności. Nie występuje ona w okresie rozwoju embrionalnego, może być w większym lub mniejszym stopniu ograniczona przez ciężkie urazy czy schorzenia. Możemy ją w pełni rozwijać, ale możemy też ją łatwo utracić. Godność aktualnie świadomego podmiotu jest postawą szerokiego spektrum uprawnień, jak np. prawo do wiedzy i szukania prawdy, prawa zakorzenione w wolności, prawo do posiadania swego światopoglądu, prawo do wolności religijnej, prawo do miłości, afektywnego życia emocjonalnego.

c) Godność nabyta albo moralna, którą nabywamy przez właściwą aktualizację naszej osobowości. Osoba doskonali się poprzez rozumne i wolne czyny. Moralną godność nabywamy poprzez dobre czyny, ubogacając się sprawnościami, czyli cnotami moralnymi. Kulminacją godności moralnej jest świętość. Godność moralna o charakterze nabywanym nie jest nam dana wraz z zaistnieniem, ale kształtujemy ją poprzez zgodne z prawdą moralne postępowanie. Przez złe czyny i nabyte wady możemy ją utracić. Godność moralna jest stopniowalna, można ją mieć w niskim czy minimalnym stopniu, można ją także całkowicie utracić, ale można też wytworzyć sobie osobowość przeciwną do tej godności, złą, nikczemną i niegodną człowieka.

d) Godność relacyjna, którą otrzymujemy jako dar od wspólnoty ludzkiej, społeczności i Boga. Wiąże się ona z relacją osoby do innych osób, do społeczności i do Boga. W relacji tej brane są pod uwagę naturalne zdolności osoby, ale godność ta jest nadawana osobie z zewnątrz, przez wspólnotę ludzką czy też z góry przez Boga. Jest ona darem, który uwzględnia naturalne, międzyosobowe relacje w ramach wspólnoty rodzinnej, etnicznej, narodowej, państwowej i religijnej. Uwzględnia różne zdolności i talenty osoby, ale jest czymś więcej niż te zdolności. Z relacji społecznych wyrastają różne formy godności przyznawane i nadawane przez instytucje społeczne i państwowe ${ }^{8}$.

Andrzej Bronk wymienia trzy zasadnicze, niewykluczające się strategie uprawomocnienia tezy, że człowiekowi przysługuje godność: przez odwołanie się do przekonań religijnych, do empirycznych lub apriorycznych argumentów filozoficznych, do racji historyczno-praktycznych.

a) Pierwotnie argumentów za ontyczną godnością człowieka szukano głównie na gruncie religii. Człowiek jest istotą stworzoną na obraz i podobieństwo Boże. Według teologii katolickiej godność człowieka jest kilkustopniowa. Wyróżnia się trzy poziomy godności człowieka: poziom przyrodzony (naturalny) bycia osobą, który $\mathrm{z}$ „natury” jest wspólny wszystkim ludziom i jest związany $\mathrm{z}$ faktem bycia człowiekiem, tj. istotą obdarzoną rozumną naturą i wolną wolą; poziom nadprzyrodzony wiążący się z byciem dzieckiem Bożym, obdarzonym przyjaźnią z Bogiem i obiecaną chwałą w życiu przyszłym; poziom godności

\footnotetext{
8 T. Biesaga, Podstawy etyki i bioetyki, Kraków 2016, s. 285-296.
} 
przysługujący chrześcijanom znajdującym się w stanie łaski uświęcającej, który traci się przez grzech.

b) Filozofowie szukają zazwyczaj podstaw dla tezy o godności ludzkiej w metafizycznej koncepcji człowieka. Broniąc godności człowieka, odwołują się do prawa naturalnego rozumianego jako ogół obiektywnych norm wynikających z natury człowieka lub do jego podmiotowości, wolności i autonomii. Filozofia nie poprzestaje na samym wskazywaniu centralnego miejsca człowieka w hierarchicznym układzie całości bytu, lecz podkreśla także fakt niezdeterminowania i wolności przy dokonywaniu wyborów.

c) W strategii historyczno-pragmatycznej wyprowadza się normatywnie treści pojęcia godności człowieka $\mathrm{z}$ faktu uchybiania tej godności w przeszłości. Historyczne doświadczenia instrumentalizacji człowieka w systemach faszystowskich i komunistycznych (totalitarnych) sprawiły, że po drugiej wojnie światowej teza o godności człowieka została przyjęta w wielu konstytucjach europejskich. Podstaw dla godności człowieka szuka się też w umowie społecznej, $\mathrm{w}$ regulacjach prawnych i w prawie stanowionym, w panujących zwyczajach kulturowych i społecznych'.

Wincenty Granat dzieli uzasadnienia godności na dwie kategorie: uzasadnienia świeckie i religijne. Wśród tych świeckich wymienia on następujące kwestie: a) Człowiek przerasta cały świat rzeczy. To on decyduje o sobie, tworzy swój wewnętrzny świat, urządza świat zewnętrzny; b) Człowiek jest obdarzony rozumem i wolną wolą, dzięki czemu podejmuje on ważne decyzje dotyczące samej osoby, a także świata i Boga; c) Równa godność osób wymaga, aby były zaprowadzane bardziej ludzkie i sprawiedliwe warunki życia; d) Człowiek wyciska poprzez swoją pracę niejako piętno na przyrodzie i poddaje ją swojej woli, daje środki utrzymania życia i służy bezinteresownie innym (godność pracy ludzkiej); e) Poszanowanie godności poszczególnych ludzi i narodów zapewnia trwały pokój na świecie; f) Aktualna sytuacja człowieka w dzisiejszym świecie, szybkie przemiany techniczne i społeczno-ekonomiczne, rozwój środków komunikacji społecznej itp. wymagają poszanowania godności osoby ludzkiej. Te uzasadnienia wydobywa Wincenty Granat ze społecznego nauczania Kościoła katolickiego ${ }^{10}$.

Uzasadnienia religijne przemawiające za godnością człowieka mają swoje źródło w Piśmie Świętym i w Tradycji chrześcijańskiej. Równość ludzi, wielkość ich posłannictwa i związana z tym godność opierają się na tym, że człowiek został stworzony na obraz Boży, a jego ostatecznym celem jest uczestnictwo w życiu Boga, co stanowi osobliwą rację ludzkiej godności. W tej perspekty-

9 A. Bronk, Kategoria godności człowieka, „Annales Universitatis Curie-Skłodowska. Sectio I. Philosophia - Sociologia” 2010, nr 1(35), s. 90-95.

10 W. Granat, Godność człowieka i jej wspótczesne uzasadnienia, w: Aby poznać Boga i człowieka. Cz. 2 (O człowieku dziś), red. B. Bejze, Warszawa 1974, s. 246-247. 
wie owa godność jaśnieje pełnym blaskiem w osobie wcielonego Syna Bożego. Chrystus przez swoją naukę i życie jest dla nas wzorem postępowania wobec Boga i ludzi, przyniósł nam wizję nowego człowieka żyjącego prawdą i miłością. Godność człowieka opiera się nie tylko na posiadaniu tej samej gatunkowo natury ludzkiej, ale także na dogmacie Wcielenia i Odkupienia ${ }^{11}$. To, że Bóg stał się człowiekiem, stanowi o wielkiej godności chrześcijanina.

Teologiczne uzasadnienia godności osoby ludzkiej pojawiają się często w nauczaniu społecznym Kościoła. Bóg ukazuje godność i wielkość człowieka. To, że Bóg stał się człowiekiem, wskazuje na wysoką godność człowieczeństwa podkreślał Prymas Stefan Wyszyński i dodawał: „Godność człowieka nie zależy od tego, jaką wykonuję pracę, jakie studia ukończył, czego się nauczył, jakie zajmuje stanowisko. Wynika ona ze świadomości, że człowiek jest mieszkaniem Boga, że Bóg w nim mieszka, że ciało jego jest poświęcone Bogu, że każdy $\mathrm{z}$ nas ma nosić i czcić Boga w ciele swoim. [...] Chrześcijaństwo ustanawia we współczesnym świecie nową ocenę wartości osoby. Kryteria tej oceny są pozaekonomiczne. Chrześcijaństwo nie ocenia człowieka według tego «ile masz», tylko według tego, «kim jesteś», «jaki jesteś»"12.

W książce Pamięć i tożsamość Jan Paweł II podkreślał, że kategoria godności jest bardzo ważna dla chrześcijańskiego myślenia o człowieku. Jest ona szeroko stosowana w całej antropologii teoretycznej i praktycznej, w nauczaniu moralności, a nawet w dokumentach o charakterze politycznym. Godność właściwa człowiekowi nie zasadza się tylko na samym człowieczeństwie, ale bardziej jeszcze na fakcie, że w Jezusie Chrystusie Bóg stał się prawdziwym człowiekiem $^{13}$. Właściwą odpowiedzią na pytanie o człowieka jest Chrystus - Redemptor hominis, co podkreślał już znacznie wcześniej w tzw. kazaniach na Areopagu: „To człowieczeństwo osobowo zjednoczone z naturą Boga-Syna świadczy o nieporównanym wyniesieniu człowieka. Człowiek musi posiadać niezwykłą wartość w oczach Boga, jeśli dla jego odkupienia Syn Boży sam staje się człowiekiem"14.

Jan Paweł II często wskazywał, że cała chrześcijańska antropologia oparta na Ewangelii pozwala człowiekowi lepiej zrozumieć i poznać jego godność. Nadprzyrodzony charakter godności ludzkiej często podkreślał w swoich wystąpieniach jako kardynał i później jako papież. Proponował tzw. normę personalistyczną, według której miłość jest jedynym właściwym odniesieniem do człowieka. W nauczaniu społecznym Kościoła katolickiego podkreśla się, że ateizm pozbawia ideę godności człowieka jej ostatecznego uzasadnienia,

11 Tamże, s. 249-252.

12 S. Wyszyński, Kimże jest człowiek..., opr. Instytut Prymasowski Ślubów Narodu, Warszawa 1987, s. 86.

13 Jan Paweł II, Pamięć i tożsamość. Rozmowy na przełomie tysiącleci, Kraków 2005, s. 115-118.

14 K. Wojtyła, Kazanie na Areopagu. 13 katechez, red. M. Wolańczyk, Kraków 2018, s. 79. 
a czysto świeckie pojmowanie godności nie do końca jest przekonujące, gdyż niesie ze sobą zubożenie dla całościowej koncepcji godności osoby ludzkiej ${ }^{15}$.

W charakterystyce postaw i zachowań progodnościowych ważne jest także zwrócenie uwagi na ogólne i szczegółowe uzasadnienia godności ludzkiej. Oprócz uzasadnień teologicznych (np. podniesienie człowieka do godności dziecka Bożego) ważne są różne uzasadnienia filozoficzne, zwłaszcza te przynależne do nurtów personalistycznych. Przed Bogiem wszyscy ludzie mają tę samą godność, niezależnie od kultury, religii, narodowości, grupy etnicznej czy rasy. W procesie odkrywania godności ludzkiej uzasadnienia naturalne są równie ważne jak uzasadnienia nadprzyrodzone (religijne). Sprawiają, że uzasadnienie godności ludzkiej nie załamuje się po odrzuceniu argumentów natury religijnej. Uzasadnienia naturalne powodują także, że kategoria godności może znaleźć się u podstaw współczesnych państw chcących się uważać za neutralne religijnie i światopoglądowo ${ }^{16}$.

Godność osoby ludzkiej stanowi wyłączną wartość człowieka, jest przynależna człowiekowi jako bytowi zajmującemu wyjątkowe miejsce w świecie przyrody. W wymiarze naturalnym godność wyraża zdolność człowieka do świadomego i wolnego działania, do rozwoju intelektualnego i moralnego (antropologia filozoficzna). W porządku naturalnym godność człowieka jest określana przez rozum, wolę i sumienie. Ze względu na godność przyrodzoną i nadprzyrodzoną nigdy nie można człowieka traktować jak rzecz, narzędzie czy środek do celu w różnych strukturach społecznych. W rodzinie, społeczeństwie, państwie, kulturze, polityce i gospodarce człowiek musi być zawsze traktowany jako podmiot. Niektóre z tych społeczności, np. rodzina, są niezbędne dla zaistnienia i prawidłowego rozwoju człowieka, inne zaś warunkują jego pełny rozwój. Uzasadnienia teologiczne godności człowieka są wiążące dla chrześcijan, uzasadnienia filozoficzne mają zaś znaczenie dla ludzi niewierzących lub o innych przekonaniach religijnych ${ }^{17}$.

Z socjologicznego punktu widzenia przyjmuje się, że człowiek jest z natury istotą społeczną i podmiotem życia społecznego. W świetle tego założenia twierdzi się, że człowiek rodzi się ludzki, ale swoją osobowość kształtuje pod wpływem społeczeństwa i kultury. Osobowość jednostki zawiera w sobie strukturę czynników biogennych, psychogennych i socjogennych, wpływających na zachowania człowieka. Aspekt socjogennych elementów osobowości określany jest niekiedy jako osobowość społeczna. Składają się na nią wartości, normy

15 W. Piwowarski, ABC katolickiej nauki społecznej. Część 1 (Wprowadzenie, podstawy, kierunki), Pelplin 1993, s. 50-53.

16 A. Dylus, Godność człowieka: fundament wartości europejskich, „Teologia i Człowiek” 2004, nr 3, s. 11 .

17 S. Fel, Jan Paweł II a prawa człowieka, w: De revolutionibus orbium populorum Joannis Pauli II. Papież wobec wykluczenia społecznego, red. K. Pilarczyk, G. Sokołowski, Warszawa 2015, s. $135-137$. 
i wzory zachowań, a także wzory ról społecznych oraz postawy jednostki wobec różnych elementów rzeczywistości. Dla socjologa godność ludzka jest wpisana w kontekst społeczny, w życie społeczne tworzone przez ludzi, dla ludzi i za sprawą ludzi ${ }^{18}$.

Jeżeli mówimy, że człowiek powinien zajmować naczelne miejsce w programach i działaniach we współczesnym świecie, to oznacza, że powinien być on celem wszelkiej działalności we wszystkich sferach życia rodzinnego, zawodowego, społecznego, narodowego i międzynarodowego. Wyniesienie człowieka do wymiaru nadprzyrodzonego wzmacnia jeszcze tę podmiotowość człowieka. Powinien być on traktowany w tych działaniach i procesach społecznych zawsze jako cel, a nie środek. To kryterium godnościowe dotyczy nie tylko poszczególnych osób ludzkich, ale i całych systemów ideologicznych, społecznych czy ustrojowych ${ }^{19}$.

Nadprzyrodzony i naturalny charakter godności osoby ludzkiej nie są od siebie oddzielone czy tym bardziej przeciwstawne. Jedna i ta sama godność przysługuje każdej istocie ludzkiej. W nauczaniu społecznym Kościoła katolickiego podkreśla się, że „godność jest wprawdzie człowiekowi przez Boga dana i że jest ona przez rozwój relacji między Bogiem i człowiekiem poszerzana i pogłębiana, ale jest ona także człowiekowi zadana, to znaczy, że sam człowiek przez pracę swojego sumienia, przez zdobywanie mądrości i wykonywanie wolności może się w tej godności rozwijać i postępować, może doskonaląc swoją osobowość coraz pełniej stawać się człowiekiem, a zatem wzrastać w godności przez współdziałanie z Bożą łaską. Dlatego to Paweł VI wielokrotnie wzywał, ażeby człowiek w swych działaniach i dążeniach dopuszczał do głosu raczej pragnienie ażeby «być», aniżeli ażeby «mieć»" ${ }^{20}$.

Uznanie godności osoby ludzkiej opiera się na czynnikach teologicznych i filozoficznych, należy je rozważać zarówno w aspekcie nadprzyrodzonym, jak i przyrodzonym (naturalnym). W kontekście tych twierdzeń stawiamy pytanie o uzasadnienie godności ludzkiej, z czego ona tak naprawdę wynika? Co czyni człowieka naprawdę godnym i w czym tkwi istota godności, jaką przypisuje się bytowi ludzkiemu? Czy godność uzasadnia samą siebie? Czy niezbędny jest Absolut, aby zaprowadzić ład w świecie wartości? Jak badana młodzież akademicka i szkolna uzasadnia ideę godności człowieka, jakie uzasadnienia uznaje za priorytetowe? Dlaczego człowiek posiada wewnętrzną godność, niezależną od okoliczności i od wartości, jaką jej przypisują różne państwa, nurty intelektualne czy ideologie?

18 P. Hodgkiss, A moral vision: human dignity in the eyes of the founders of sociology, „The Sociological Review" 2013, nr 3(61), s. 417-439.

19 H. Piluś, Godność osobowa jako podstawa i uzasadnienie niezbywalnych praw $i$ wolności człowieka, w: Prawa i wolności człowieka w edukacji demokratycznego państwa. Materiały I Ogólnopolskiej Konferencji Naukowej Siedlce-Chlewiska 7-8 grudnia 1999 r., red. R. Rosa, Siedlce 1999, s. 73-74.

20 J. Majka, Etyka społeczna i polityczna, Warszawa 1993, s. 21. 


\section{Uzasadnienie godności ludzkiej w opinii młodzieży}

Źródła godności ludzkiej wskazywane przez badaczy społecznych są różnorodne. Janusz Gajda streszcza je następująco: „Godność ludzka, można rzec, wynika z natury człowieczej, co znajduje odzwierciedlenie w różnorodnych dogmatach religijnych, przeświadczeniach o roli człowieka w świecie oraz $\mathrm{w}$ stanowionych prawach. Zasadza się ona na powszechnym przeświadczeniu o wyjątkowej roli człowieka jako istoty rozumnej w świecie, człowieka przez Boga stworzonego na Jego obraz i podobieństwo, a zatem podniesionego niemalże do godności boskiej w religii chrześcijańskiej czy wręcz utożsamianego z bogiem w New Age"21.

Badana młodzież z różnych środowisk społecznych odpowiadała na pytanie o uzasadnienie godności ludzkiej. Uzyskane odpowiedzi zgrupowaliśmy w kilka podstawowych kategorii. Wypowiedzi respondentów są opatrzone następującymi znakami: „A” - studenci Wyższej Szkoły Nauk Społecznych z siedzibą w Lublinie; „P” - studenci Pedagogiki KUL; „O” - studenci Uniwersytetu w Warmińsko-Mazurskiego w Olsztynie; „\$” - młodzież szkół średnich w Stalowej Woli. Przeprowadzone badania empiryczne pozwoliły ukazać różnorodność i złożoność doświadczeń związanych z godnością ludzką, rozmaitość sposobów jej interpretacji, nadawania znaczenia i sensu. Analizowane określenia i uzasadnienia godności ludzkiej pojawiały się w wypowiedziach młodzieży $\mathrm{z}$ różną częstotliwością, niekiedy w różnorodnych powiązaniach między sobą.

a) Godność ludzka w kontekście uzasadnień teologicznych, odwołujących się do religii, Objawienia Bożego, do Boga jako Stwórcy natury ludzkiej. $\mathrm{W}$ aspekcie nadprzyrodzonym ukazuje ona udział człowieka w rzeczywistości transcendentnej, w życiu Osób Bożych (antropologia biblijna). Człowiek został stworzony na podobieństwo i obraz Boży (imago Dei). Źródłem równej, ontologicznej godności wszystkich ludzi jest Bóg, to On jest dysponentem dignitas humana. Godność osobowa ma charakter absolutny i nie można jej przypisywać jednostkom w stopniu większym lub mniejszym. Myślą przewodnią społecznego nauczania Kościoła i w konsekwencji katolickiej nauki społecznej jest wrodzona i nadprzyrodzona godność osoby ludzkiej. Osobę ludzką należy szanować, gdyż jest ona miraculum mundi. Wszystkie rzeczy i przedmioty mają cenę i są wymienialne na rynku, osoba ludzka zaś ma godność, na obliczu każdej osoby ludzkiej jaśnieje blask Boży²2.

Teologiczne uzasadnienia godności osoby ludzkiej pojawiały się w niektórych wypowiedziach badanej młodzieży: „Moim zdaniem uzasadnieniem ludzkiej

21 J. Gajda, Wartości w życiu i edukacji człowieka, Toruń 2013, s. 131-132.

22 F,J, Mazurek, Katolicka nauka społeczna - status metodologiczny i główne obszary problemowe, w: Katolicka nauka społeczna. Podstawowe zagadnienia z życia społecznego i politycznego, red. S. Fel, J. Kupny, Katowice 2007, s. 30. 
godności jest fakt, iż Bóg stworzył człowieka na swój obraz, dlatego godność jest jedną z najważniejszych wartości w życiu, o którą należy dbać” $(\mathrm{O})$; „Uznaję godność ludzką za wartość, uzasadniam to tym, że najważniejsza w życiu człowieka powinna być wiara w Boga, ale także umiłowanie swojej ojczyzny" (P); „Godność jest przynależna człowiekowi, życie z godnością to życie według zasad, np. moralnych (własnych) - stąd jest wartością bycie godnym człowiekiem. Człowiek został stworzony na podobieństwo Boga” (S); „Godność ma każdy człowiek, niezależnie od stanowiska pracy czy miejsca w społeczeństwie czy jego uczynków. Bóg obdarzył człowieka godnością bezwarunkową i nie możemy jej pozbyć się" (P); „Godność ludzka to naturalna właściwość każdego człowieka, to dar, który otrzymaliśmy od Stwórcy. Przysługuje ona każdemu niezależnie od płci, wyznania, koloru skóry” (P); „Jest wartością niezbywalną i wynika już $\mathrm{z}$ faktu naszego zaistnienia. Tego, że jesteśmy ludźmi, istotami stworzonymi na obraz Boga. Godność ludzka jest wartością, ponieważ niesie ze sobą takie postrzeganie oraz nadaje takie cechy, które są pozytywne, pozytywnie wpływają na człowieka i prawidłowo go kształtują” (P); „Według mnie godność ludzka jest wartością, ponieważ samo słowo wartość wskazuje na coś pozytywnego, coś, czym warto się kierować w życiu. Jak wiadomo, godność również jest czymś pozytywnym. Poprzez postępowanie zgodnie z jej wskazaniami człowiek wzrasta w swym człowieczeństwie, zbliża się do Boga. Ponadto szanowanie godności innych ludzi również prowadzi do pozytywnych następstw (np. polepszenie stosunków), co niewątpliwie wskazuje na to, że godność jest wartością" (A); "Godność ludzka jest dla mnie wartością, ponieważ pochodzi od Boga i jest przypisana każdemu człowiekowi. W związku z tym jest dla mnie bardzo istotna w życiu i staram się ją respektować poprzez docenianie samej siebie oraz ludzi, z którymi przebywam” (A); „Chcąc uzasadnić, że godność ludzka jest wartością, myślę, że trzeba odnieść się do Boga, który jest źródłem tej godności. Obdarzył człowieka nieśmiertelną duszą i wolnością, których nie mają np. zwierzęta. Niestety, we współczesnym świecie niewielu ludzi zdaje sobie sprawę z tego, że godność jest darem” (A); „Moim zdaniem uzasadnieniem ludzkiej godności jest fakt bycia dzieckiem Bożym. Przez Jezusa Chrystusa staliśmy się dziećmi Boga, zostaliśmy przez Niego odkupieni, a co więcej, zostaliśmy stworzeni na obraz i podobieństwo Boga" (A).

Teologiczne uzasadnienia godności osoby ludzkiej pojawiały się niezwykle rzadko w wypowiedziach badanej młodzieży szkolnej i akademickiej. Jeżeli nawet większość Polaków byłaby intuicyjnie zdolna opisywać człowieka i jego godność w odniesieniu do Boga i Jego działania, a na pytanie wprost o to, czy godność człowieka jest darem Boga, odpowiedziałaby twierdząco, to badania socjologiczne nie potwierdzają tego, że młodzież postrzega spontanicznie człowieka i jego godność - poza nielicznymi wyjątkami - w perspektywie teologicznej. Z pewnością tylko nieliczni rozumieją godność ludzką w całkowitym 
oderwaniu od jakichkolwiek relacji z Bogiem osobowym. W bezpośrednich narracjach perspektywa teologiczna pojawia się jednak nader rzadko, co może wskazywać na to, że młodzież niejasno uświadamia sobie głębszy i teologiczny sens godności ludzkiej. Jeżeli nawet religijny wymiar godności ma znaczenie dla ludzi wierzących, to w praktyce, w spontanicznych wypowiedziach na ogół się nie liczy, a w każdym razie rzadko jest postrzegany i artykułowany. Do argumentów teologicznych odwołują się ci, dla których religia jest nie tylko wiarą w dogmaty czy kultem, ale poszukiwaniem głębszych odpowiedzi na pytania związane z ludzką egzystencją.

b) Godność ludzka jako wartość szczególnie ważna, nawet najważniejsza. Osoba ludzka posiada swą godność, nie otrzymując jej od innych. W świetle bytów stworzonych jest jedyną rzeczywistością posiadającą wartość per se, jest wartością najwyższą i bezwzględną. Nigdy nie może być traktowana jako środek do celu innego człowieka czy społeczeństwa. Jest w pełni autonomiczna, ale równocześnie człowiek ustawicznie wchodzi w relacje z innymi osobami, równymi w swej godności i wolności ${ }^{23}$. Ze względu na swoją transcendentną godność człowiek przewyższa wszelkie byty stworzone, zachowuje też prymat w życiu społecznym. W stosunku do wszystkich urządzeń społecznych osoba ludzka jest i powinna być zasadą, podmiotem i celem. Jest ona najogólniejszą normą i podstawą całego ładu społeczno-gospodarczego.

„Godność pełni w życiu duża rolę, ma ogromne znaczenie. Jednostki okazują szacunek do godności. Jest to niezbędne do naszego istnienia” (S); „Uważam godność ludzką za wartość w teraźniejszych czasach, ponieważ coraz bardziej zanika ona w społeczeństwie” (S); „Dla mnie jest to najważniejsza wartość, poszanowanie życia, siebie i innych, to traktowanie pozytywne bez względu na inność. Życia nie można zabrać, każdy zasługuje na własne poglądy, na własny styl życia, na własne uczucia” (S); „Jest to najważniejsza, bądź jedna z najważniejszych cech, które posiada człowiek. U każdego jest opisywana inaczej, stąd jest ciężko uznać jedną konkretną definicję” (P); „Na godność ludzką zasługuje każda osoba. Jako wartość godność ludzka jest bardzo potrzebna każdemu człowiekowi, ponieważ czuje się potrzebny” (P); „Godność ludzka jest bardzo ważną wartością i należy ją pielęgnować” (A); „Jest to godność pożądana przez ludzi, społeczeństwo. Ma ona znaczenie zarówno symboliczne, jak i «materialne» w tym sensie, że większa część ludzi uznaje, że jeżeli jest się człowiekiem godnym, to jest się również osobą wartościową (coś znaczącą)” (O); „Myślę, że godność ludzka wyraża się między innymi w poczuciu własnej wartości, tzn. to jestem ja, należę do tej grupy społecznej, identyfikuję się z tymi poglądami i nikt nie może w żaden sposób tego negować, chyba że one w swojej istocie godzą

23 F. Adamski, Poza kryzysem tożsamości, w kierunku pedagogiki personalistycznej, w: Poza kryzysem tożsamości, w kierunku pedagogiki personalistycznej, red. F. Adamski, Kraków 1993, s. 12. 
w godność ludzką” (O); „Ludzka godność jest właśnie wartością. Za wartość uznawana była już od bardzo dawna, udowadnia to chociażby obecne prawo, które uznaje ludzką godność jako niezwykle istotną kwestię ściśle związana z ludzkim życiem. Zatem godnością ludzką jest właściwie wartość człowieka, która powinna zajmować szczególne, najwyższe z miejsc wśród hierarchii wartości człowieka" (A).

Przytoczone powyżej uzasadnienia godności ludzkiej mają w dużej mierze charakter deklaratywny („godność to wartość najwyższa, którą powinien popierać każdy uczciwy człowiek"), połączone są nawet z pewną formą egzaltacji („godność jako wartość powinna być na pierwszym miejscu; godność jest najwyższą wartością, którą każdy człowiek powinien mieć na uwadze. Każdy powinien o nią walczyć, do niej dążyć”). Uzasadnienia te mają znaczenie dla jednostki, są wyrazem jej wewnętrznych przekonań, ale nie mają lub tylko w niewielkim stopniu moc argumentacji obiektywnej.

c) Godność ludzka jako coś danego, nieutracalnego, niezbywalnego, „Z urodzenia”. Godność człowieka jest wpisana w jego strukturę bytową, w związku z czym posiada rangę czegoś nienaruszalnego i niezależnego, co nie może być poddawane w wątpliwość. Jest ona określana jako wartość wrodzona, niepodzielna i niezbywalna. Nazywa się ją godnością ludzką, godnością bytu ludzkiego. Nikt nie może wyrzec się swej ontycznej struktury. W pojęciu godności osobowej zawiera się to wszystko co, konstytuuję istotę człowieka i równocześnie konstytuuje jedność rodzaju ludzkiego. Jest ona wartością powszechną, przysługującą każdemu człowiekowi, od poczęcia do naturalnej śmierci. Wszyscy ludzie są pod tym względem sobie równi, godność jest wartością ontyczną.

„Godność to wartość człowieka, z którą się rodzi, której nikt nie może mu zabrać. Człowiek sam się może pozbyć swojej godności, kiedy to popełnia grzechy, łamie prawo oraz wszelkie przepisy, kiedy to nie ma szacunku do drugiego człowieka” (P); „Godność ludzka jest wartością, ponieważ każdy człowiek ją ma od urodzenia i jest ona niezbywalna. Jest częścią każdego z nas” (P); „Godność ludzką można uznać za wartość, a nawet trzeba z racji tego, że przysługuje ona każdemu człowiekowi bez względu na to, czy jest on kobietą, czy mężczyzną i jakie ma pochodzenie. Realizuje się ona w wielu dziedzinach życia, jesteśmy wolnymi ludźmi i mamy prawo do podejmowania słusznych nam decyzji, budowania wzajemnych relacji z innymi ludźmi, życia we wspólnocie oraz budowania wzajemnych relacji z bliskimi” (P); „Coś, z czym się rodzimy, nikt tej wartości nie może nam odebrać. Jest to coś wpisanego w nasze życie, jest jedną z wartości ważnych w ludzkim życiu” (P); „Mówiąc o godności ludzkiej jako o wartości można stwierdzić, iż każda osoba ją posiada, jednakże nie każda jednakowo postrzega. Może być uznana za jedną z najważniejszych wartości człowieka” (A); „Godność ludzka jest najwyższą wartością według mnie. Nikt $\mathrm{z}$ nas nie ma prawa pozbawiać jej drugiego człowieka. Godność - jako nie- 
zbywalne prawo" (A); „Jest to jedna z największych wartości. Każdy powinien ją cenić zarówno u siebie i respektować godność innych osób. Według mnie uzasadnienie jest proste, godność jest przypisaną każdemu człowiekowi wartością z góry i jeżeli sam jej sobie nie odbierze, powinna być jego nieodłączną częścią” (O); „Godność ludzką jako wartość mogę uzasadnić tak, że jest to coś, czego nie można kupić, ani sprzedać. Wartość, która w pewnym stopniu może być utracona, ale z własnej inicjatywy. Jest to coś, czego nie można odebrać człowiekowi całkowicie” $(\mathrm{O})$; „Źródłem jest jej - według mnie - posiadanie swojej własnej wartości, człowiek posiada ją od urodzenia, od poczęcia - dla mnie, gdy szanujesz samego siebie i inni ciebie szanują, ale za podstawę trzeba mieć szacunek samego do siebie" (S).

W uzasadnieniach powyższych zaakcentowana jest „wrodzoność” i „nieutracalność” godności człowieka. Człowiek rodzi się osobą z przysługującą mu godnością, a nie jest przez kogoś czy przez coś kreowany na osobę. Status osoby nie jest udzielany przez innych, przysługuje każdemu człowiekowi z natury, na mocy samego istnienia, jest cechą immanentną człowieka, „koegzystuje” z jego życiem. Z tego, że człowiek jest celem samym w sobie, wynika zobowiązanie respektowania ludzkiej godności w sobie samym i w innych, w każdej istocie należącej do gatunku ludzkiego. Dzięki przyrodzonej godności człowiek posiada niezaprzeczalne prawa, wrodzone a nie nabyte, które nie mogą być przez nikogo naruszane.

d) Godność ludzka jako człowieczeństwo. Fundamentalna godność osoby ludzkiej jest wrodzona, właściwa wszystkim ludziom i niezbywalna, nie można przeliczyć jej na cokolwiek innego, zamienić na pieniądze czy inne dobra materialne. Każdy człowiek ze względu na to, że jest człowiekiem, ma prawo do szacunku i respektowania jego praw. Godność jest należna każdemu człowiekowi ze względu na fakt bycia człowiekiem (człowieczeństwo). Poniżanie człowieczeństwa przejawia się w instrumentalnym i egoistycznym traktowaniu innych ludzi. Człowiek zdolny jest rozpoznać swoją godność mocą naturalnego rozumu, ale w pełni może zrozumieć, kim jest człowiek, w świetle Objawienia Bożego.

„Godność ludzka jest dla mnie ogromną wartością, ideałem byłoby traktowanie innych z poszanowaniem ich poglądów, wierzeń, przekonań, niezależnie od tego, kto kim jest, należy ukazywać poczucie szacunku. Jest to wartość pierwotna, przynależna każdemu, bez żadnych wyjątków” (S); „Myślę, że godność można uzasadnić jako podstawową wartość, wartość niezbywalną, przypisaną każdemu człowiekowi” (P); „Godność ludzka dana jest człowiekowi od samego początku i to jest wartość, wartością jest człowiek, a z tym się łączy jego godność" (P); „Jest to wartość niezbywalna i przysługuje każdemu człowiekowi. Jest wartością tak bardzo podstawową jak zdrowie człowieka. Bez niej żaden człowiek nie może czuć się dobrze, szczęśliwie i godnie. Godność to również wolność ograniczona jedynie wolnością i dobrem drugiego człowieka” (A); „Godność 
ludzka jest podstawową wartością człowieka, wiąże się z miłością, szacunkiem i odpowiedzialnością. Godność człowieka jest naturalną właściwością, istotą człowieczeństwa” (A); „Godność ludzka jest wartością, bezwzględnie należy się każdemu człowiekowi. Wartość samostanowienia, poczucia własnej wartości, szacunku” (A); „Wartość każdego człowieka, podstawa istoty człowieczeństwa, zespół praw każdego człowieka” (A); „Bez godności ludzkiej, bez szacunku do człowieka, staje się on w oczach innych kimś gorszym, może być traktowany jak zwierzę. Godność ludzka należy się przez samo człowieczeństwo" $(O)$; "Godność człowieka jest wartością, ona nierozerwalnie łączy się z faktem bycia człowiekiem, nie można mówić o godności zwierząt, aczkolwiek zwierzęta jako stworzenia Boże też należy szanować, w takim sensie, że nie można się nad nimi znęcać. Godność człowieka jest czymś ważnym i myślę, że ma wpływ na stosunki międzyludzkie, powinna być zawsze brana pod uwagę w relacjach międzyludzkich" (P).

Godność - według wyżej przytoczonych wypowiedzi - to fakt przyrodzony, rodzajowy atrybut człowieka, nierelatywny i niezbywalny, związany z jego kondycją jako istoty rozumnej, wewnętrznie wolnej, zdolnej do odróżniania dobra od zła oraz do intencjonalnych działań. Przysługuje ona wszystkim ludziom ze względu na fakt bycia człowiekiem. Godność w tym ujęciu jest równoznaczna ze samym człowieczeństwem. Uznanie godności pierwotnej, przynależnej człowiekowi ze względu na sam fakt bycia człowiekiem, nakazuje traktować wszystkich ludzi z szacunkiem i respektować podstawowe prawa związane z ich tożsamością indywidualną, społeczną, kulturową i religijną. Człowieczeństwo stanowi nieodwołalną godność osoby ludzkiej, godności każdej osoby, w każdej fazie i kondycji jej egzystencji.

e) Godność ludzka uzasadniana przez inne wartości, jak: szacunek ludzki, życie, wolność, rozumność, sumienie. Najogólniej przez godność rozumie się wyjątkową wartość człowieka jako osoby. Człowiek jest osobą, tzn. jest istotą rozumną i wolną. Rozum sprawia, że człowiek poznaje świat taki, jakim ten świat rzeczywiście jest. Wolność jest zdolnością do dokonywania wyborów. Człowiek sam sobie dobiera przyjaciół, doradców, sam wybiera sobie ideały życiowe i swój życiowy los. Rozum i wolność sprawiają, że człowiek nie jest osobnikiem, lecz osobą, istotą niepowtarzalną, jedynym w swoim rodzaju indywiduum. Osoba ludzka może być wyłącznie celem, a nie środkiem naszych działań. Nie można człowieka używać tak, jak używa się narzędzi. Jako posiadający rozum i wolę człowiek może odkrywać swe własne cele, ponieważ posiada przywilej wolności, sam może zmierzać do wytkniętych celów. Człowiek jest wartością pierwotną i absolutną, nie trzeba jej uzasadniać, gdyż uzasadniają ją inne wartości, przede wszystkim to, że człowiek jest istotą rozumną, działającą w sposób wolny i odpowiedzialną za swoje czyny. 
„Ja uważam, że najważniejszy jest szacunek do życia, każdy zasługuje na godne traktowanie” (S); „Wartość ta powinna być na pierwszym miejscu, każdy ma prawo do szacunku” (S); „Uznając godność ludzką za wartość i chcąc to uzasadnić, trzeba by uzasadniać też wiele innych wartości ściśle związanych z godnością człowieka. Myślę, że jedną z tych związanych z nią wartością jest wolność. Ta wartość również ma wiele znaczeń. Podkreślić chciałbym wolność sumienia i wolność w znaczeniu prawa do decydowania o swoim życiu właśnie według przekonań, sumienia. Człowiek poprzez wolność może ujawniać swoją wartość. Nie jest maszyną, potrafi kochać” (P); „Godność człowieka wyraża się właśnie w szacunku do danej osoby, akceptacji człowieka jako całości, jego prawa do życia” (P); „Człowiek jest istotą rozumną i powinien szanować siebie i innych” (A); „Godność ludzka jest według mnie wartością, ponieważ wiąże się z życiem ludzkim, a życie jest pięknym darem, który powinniśmy w pełni szanować i dbać o dobro i szacunek dla bliźniego, jak również dla samego siebie" (A); „Można traktować ludzi równo bez względu na pochodzenie czy status materialny. Należy traktować ludzi szczególnie pośród innych istot żywych. Życie ludzie jest wartością, która podkreśla godność człowieka, bo samo życie ludzkie jest bezcenne” (A); „Jeżeli przyjmujemy godność ludzką za wartość, to myślę, że jest to coś, co każdy z nas powinien posiadać i postępować tak, aby pielęgnować tę wartość i żyć zgodnie z jej zasadami. Myślę, że godność każdy ma w sobie i wywodzi się z jego własnych poglądów i systemu wartości” $(\mathrm{O})$; „Uznaję godność za wartość, podobnie jak wartości rodzinne, sprawiedliwość, czy uczciwość. Jest ważna, ponieważ sprawia, że jesteśmy tym, kim jesteśmy, mamy własne zdanie i poczucie, że jesteśmy dzielną jednostką. Podobnie jak inne wartości jest chroniona przez ludzi, dla których jest ważna” $(\mathrm{O})$; „Uznaję godność ludzką za zbiór wielu wartości” $(\mathrm{O})$; „Godność ludzką można uzasadnić jako wartość duchową, emocjonalną i życiową" (P).

Uzasadnienie tezy o osobowej godności człowieka może być natury metafizycznej lub opierać się na pewnych cechach podstawowych człowieka (racjonalność, zdolność do samowiedzy, wolna wola, niepowtarzalność jednostki w świecie, niesprowadzalność do żadnego innego bytu). Niekiedy traktuje się twierdzenie o godności każdej jednostki jako rodzaj moralnego aksjomatu. Niektórzy spośród ankietowanej młodzieży stawiają godność na równi z wolnością i równością, większość z nich - prawdopodobnie - nie byłaby w stanie wyjaśnić relacji pomiędzy tymi wartościami. Są i tacy, którzy uznają, że godność człowieka wynika z jego wolności, autonomii i podmiotowości. Godność jako pojęcie pierwotne oznacza, że nie można go zdefiniować za pomocą innych wartości. Jej sens można przybliżyć przez dookreślenie, używając takich terminów jak życie, wolność, sprawiedliwość, życzliwość, szacunek, sumienie, odpowiedzialność lub łącznie kilka wartości. Warto wyraźnie podkreślić, że 
wartości, na które powołują się respondenci w uzasadnianiu godności ludzkiej, wynikają z godności i w niej mają swoją legitymizację, a nie odwrotnie.

f) Godność ludzka jako gwarancja i przejaw życia moralnego. Godność ludzka motywuje człowieka do działań zgodnych z wyznawanym systemem wartości, nie pozwalając na odstępstwa od przyjętych wartości i norm. „Miej godność” znaczy: „bądź szlachetny”, „bądź uczciwy”, „bądź dostojny”, „postępuj zgodnie z sumieniem". Godność w tym znaczeniu można posiadać w różnym stopniu, można ją także utracić. Człowiek w tej koncepcji wykazuje się godnością lub się nią nie wykazuje w zależności od swoich cech i od indywidualnego sposobu postępowania, a także od warunków zewnętrznych o charakterze obiektywnym. Godność rozwija się podobnie jak i inne właściwości człowieka. W sytuacjach osobistego zagrożenia człowiek traci swoją godność, utrzymuje ją lub ją odzyskuje. Odnosząc zwycięstwo w czasie ,próby”, zyskuje szacunek moralny na długi czas, z kolei przegrywając, podlega deprecjacji moralnej $\mathrm{w}$ swoich odczuciach i w ocenie otoczenia społecznego ${ }^{24}$. Godność pojawia się zarówno wtedy, gdy sami nie czynimy niczego, co uwłacza godności innych, jak i wtedy, gdy nie godzimy się na poniżanie naszej godności (w obydwu przypadkach staramy się ,,zachować twarz"). Tak rozumiana jest w pewnym sensie funkcją kształtowania się świadomości, można ją odpowiednio udoskonalać, rozwijać, kształtować i dopełniać.

„Godność ludzka oddziałuje na nasze zachowanie. Jest najwyższą wartością, bo bez niej człowiek czuje się pusty i niezgodny z własnym «ja»” (S); „Uzasadnić godność można zachowaniem człowieka. Skoro człowiek szanuje samego siebie, zachowuje się w sposób, który nie jest dla niego w żaden sposób kompromitujący, nie sprowadza go do zażenowania” (S); „Uzasadnić godność ludzką można poprzez zachowanie drugiego człowieka” (S); „Godność ludzka jest wartością, gdyż człowiek, który kieruje się w życiu wartościami, będzie człowiekiem prawym, szanowanym przez społeczeństwo. Można tutaj przytoczyć przykład kobiety, która jest rozwiązła. Poprzez takie zachowanie godzi w siebie i swoje ciało” (S); „Każdy człowiek ma prawo do godności, czyli szacunku i uznania jego postępowania. Człowiek godny postępuje zgodnie $\mathrm{z}$ własnymi zasadami i moralnie” (S); „Godność ludzka jest wartością, ponieważ każdy człowiek ma w swoim życiu jakieś wartości, które wyznaje, według których żyje i tak jak wartości, którymi się kieruje w swoim życiu, te które uważa za ważne, godność ludzka również jest taką wartością. Stanowi ona fundament życia ludzkiego. Bez godności ludzkiej życie człowieka nie miałaby sensu, dlatego godność ludzką można nazwać wartością” (P); „Godność jest wartością, ponieważ sprawia, że ludzie są dobrzy i serdeczni dla siebie. Miło jest wtedy żyć i załatwiać codzienne sprawy. Nawet codzienne kontakty międzyludzkie mogą być wtedy oparte na

24 M. Ossowska, O człowieku, moralności i nauce, Warszawa 1983, s. 52-53. 
zrozumieniu, pomocy, rozmowie. Nikt nie przechodzi obok potrzebujących obojętnie, widzi innych i chce żyć z nimi w pełni. Już nie przechodzi obojętnie obok innych ludzi i nie udaje, że nie widzi drugiego człowieka. Rodzice mają czas dla dzieci, a nie uciekają do pracy. To dla mnie bardzo ważne i chciałabym żyć i wzrastać w świecie wartości, które widzę, a nie słyszę tylko o nich w szkole" (A); „Godność ludzką jako wartość można określić zachowaniem człowieka” (A); „Godność jest wartością, która pozwala funkcjonować w społeczeństwie bez zbędnego stresu. Godność to szacunek do siebie i innych, przeżywanie życia na właściwym poziomie społecznym i moralnym” (O); „Uważam ją za wartość, ponieważ jest w każdym z nas. Bez niej człowiek nie wiedziałby o granicach" (O); „Godność człowieka możemy uznać za wartość, ponieważ jest to cenna cnota. Bez godności człowiek stałby się swoistym potworem, który miałby za nic szacunek do samego siebie, jak i do innych ludzi. Godność możemy porównać do honoru, ludzie bez owej cnoty mieliby za nic innego człowieka i swoje wyznawane wartości” (O); „Jest to niezbędny czynnik porządku społecznego, gdyż brak szacunku ludzi do siebie prowadzi do jego załamania. Nikt nie lubi być zmuszanym. Respekt ułatwia komunikację między ludźmi” (O).

Godność nie jest tylko cechą zdobiącą człowieka, lecz wyraża istotę człowieczeństwa, skłania do doskonalenia umiejętności i cech charakteru, wierności sobie, realizacji postawionych celów, krótko mówiąc - do ciągłego podnoszenia poziomu moralnego. Wysoka ocena szacunku dla samego siebie i wartości drugiego człowieka zakłada, że ludzie będą zdolni wykraczać poza sprawy związane z własnym interesem i doceniać także wartości moralne. Człowiek godny, opierający swoją godność na zobiektywizowanych kryteriach moralnych, jest zdolny przeciwdziałać różnym formom bezładu społecznego i moralnego. Godność osoby ludzkiej jest celem i zasadą wszelkiego wychowania społecznego i moralnego. Jako styl życia moralnego godność jest związana z wartościami, które łatwo naruszyć lub stracić. To jest do pewnego stopnia zbiór zasad etycznych, indywidualnych dla każdego. Według nich oceniamy, czy ktoś jest dobrą osobą, czy zachowuje się rozsądnie, z respektem dla innych, zgodnie z własnym sumieniem, czyli właśnie godnie. To godność osobowa sprawia, że człowiek nie może być traktowany jako rzecz, narzędzie czy środek w strukturach społecznych (np. większe lub mniejsze społeczności, państwo), czy w różnych dziedzinach życia społecznego.

g) Godność ludzka jako wartość wychowawcza. Godność może i powinna stać się podstawową wartością w wychowaniu, które jest procesem rozwoju osoby. Chodzi tu przede wszystkim o ukazywanie wartości godnościowych jako służących pełnemu rozwojowi człowieka, promowanie ich wśród ludzi, zwłaszcza ludzi młodych, ale i odczytywanie kontekstów społecznych ułatwiających albo utrudniających realizację tych wartości. Wychowanie progodnościowe jest wychowaniem personalistycznym. Kluczową sprawą jest w nim rozwijanie 
poczucia godności oraz kształtowanie woli postępowania w sposób godny, tj. ludzki wobec innych osób. Miernikiem dojrzałego stosunku do drugiego człowieka jest sposób, w jaki go traktujemy. Mówi się, że miernikiem dojrzałości jest poszanowanie godności człowieka.

„Uważam, że godność może być wartością, ponieważ da się jej nauczyć” (A); „Godność człowieka jest bardzo ważna w społeczeństwie. Już od najmłodszych lat uczono nas o pewności siebie, o tym, żeby nie bać się własnego zdania. Jest to nauczanie o wartościach - wartość samego siebie” (A); „Uważam, że godność ludzka jest wartością, z którą się rodzimy. Jednak edukacja jest potrzebna, ponieważ $\mathrm{w}$ momencie burzliwego dorastania może zostać zachwiana przez towarzystwo, w jakim się dana osoba znajdzie” (O); „Uważam, że z godnością ludzką raczej człowiek się nie rodzi. Nabywa ją, uczy się jej w ciągu swojego życia. Ma na to wpływ wychowanie i doświadczenia, jakie przeszedł” (O); „Moim zdaniem, każdy się rodzi z wartością, jaką jest godność. Jednak wraz z wychowaniem i warunkami, w jakich żyje, dana osoba może wzrastać w tę wartość lub maleć” (O); „Godność to coś, co człowiek zdobywa wraz z wiekiem. Uczy się jej od rodziców, dziadków. To wartość, dzięki której człowiek czuje się lepszym i wartościowszym. Utrata godności to utrata człowieczeństwa” (O); „Jeśli dobrze zrozumiałam pytanie, że godność ludzka jest zależna od wychowania zarówno przez rodzinne grono, jak i ogół społeczeństwa. Zależy także od tego, w jakim otoczeniu się znajdujemy i jakie mamy wartości w życiu" (P).

W wychowaniu nie chodzi tylko o ukształtowanie takich usprawnień jak komunikatywność, życzliwość czy grzeczność, bezpieczeństwo materialne, dobre wykształcenie, intratny zawód, poprawne stosunki społeczne itp., lecz przede wszystkim o odniesienia do prawdziwej godności człowieka, z wykluczeniem instrumentalnego traktowania jego rzeczywistej godności osobowej. Wychowanie, które bazuje na rozpoznaniu godności, ujmuje wartości osobowe obligujące do afirmacji osoby i działania dla jej realnego dobra ${ }^{25}$. W wychowaniu progodnościowym człowiek otwiera się na prawdę i dobro, stara się być wierny przyjętym wartościom i kształtuje prawe sumienie.

h) Godność ludzka jako cecha odróżniająca człowieka od innych bytów stworzonych. Niektórzy uważają, że o godności człowieka decyduje jego własna natura (rozum i wolna wola). Inni utrzymują, że rozstrzyga o tym uprzywilejowane miejsce człowieka wśród istot żyjących. Być człowiekiem to być osobą, a być osobą to być kimś, a nie czymś. Człowiek jest nie tylko jednostką materialną (cielesną), ale i świadomym oraz wolnym podmiotem. Dzięki temu, że jest osobą, zajmuje kluczową pozycję w świecie przyrody, przewyższa wszystko, co

25 K. Stępień, Godność osobowa, w: Encyklopedia aksjologii pedagogicznej, red. K. Chałas, A. Maj, Radom 2016, s. 382; A. Rynio, Wychowanie do odpowiedzialności. Studium teorii i praktyki pedagogiki integralnej, Lublin 2019, s. 161-177. 
tworzy ten świat. Nie jest rzeczą wśród innych przedmiotów, zajmuje w świecie centralną, uprzywilejowaną pozycję. Każdemu człowiekowi przysługuje swoiste dostojeństwo, cześć, honor i dobre imię. Godność jako wartość absolutna nie jest odnoszona do innych wartości czy dóbr, nie ma waloru pochodnego, wynikającego z jakichś innych wartości.

„Moim zdaniem godność ludzka jest podstawową wartością w życiu człowieka. Przysługuje ona każdemu bez względu na kraj pochodzenia, rasę, płeć, czy wykonywany zawód. Wyróżnia ona człowieka spośród innych istot na ziemi, podkreśla jej wyjątkowy charakter” (A); „Bo dzięki niej różnimy się od innych stworzeñ” (A); „Godność to czynnik, który odróżnia człowieka w świecie zwierząt, od samych zwierząt. Oraz to, czy szanuje siebie, więc na pewno wysoka samoocena oraz wiara w siebie” (A); „To wartość nienabyta, ale łatwa do stracenia. To wartość, która stawia istotę ludzką ponad inne stworzenia i wyróżnia się myśleniem i szacunkiem do swojego gatunku" $(\mathrm{O})$.

Człowiek jest nie tylko jednostką materialną (cielesną) ale i świadomym i wolnym podmiotem, czyli osobą. Dzięki temu, że jest osobą, zajmuje kluczową pozycję w świecie przyrody, przewyższając wszystko, co tworzy świat przyrody. Nie jest rzeczą wśród innych przedmiotów. Dzięki godności człowiek wyróżnia się w istotny sposób w świecie istot żywych, jest panem stworzenia. Niekiedy podkreśla się swoistą niepowtarzalność jednostki w świecie.

i) Godność ludzka jako wartość nieprzestrzegana. Część filozofów współczesnych reprezentuje pogląd o niemożliwości filozoficznego uzasadnienia tezy o posiadaniu przez każdą jednostkę ludzką wartości niezbywalnej, czyli godności osobowej. Godność jest wartością, którą odczuwa się intuicyjnie, ale nie można jej określić za pomocą ścisłej definicji. Nie ma ona nic lub nie ma wiele wspólnego z obiektywną strukturą bytu ludzkiego. Według innych poczucie godności prowadzi do nadmiernej roszczeniowości, skupienia się człowieka na sobie samym z pominięciem potrzeb innych ludzi lub za przeszkodę w pragmatycznym myśleniu i skutecznym oraz racjonalnym działaniu. W skrajnych ujęciach uznaje się pojęcie godności za pustą formułę, za swoisty konstrukt, któremu nic nie odpowiada w rzeczywistości - nie ma czegoś takiego jak godność. Niektórzy nasi respondenci wskazywali na to, że w rzeczywistości godność jako wartość jest często kwestionowana w praktyce życia codziennego, należy do wartości bardzo często zagrożonych.

„Jeżeli człowiek szanuje własną osobę, jest wartościowy. Nie każdy w dzisiejszych czasach potrafi okazać szacunek do własnej osoby” (A); „Każdy człowiek jest osobą wartościową. Niestety, wielu ludzi nie szanuje drugiego człowieka, poniża go i rani. Tacy ludzie sprawiają, że samoocena człowieka spada, taka osoba uważa się za osobę niewartościową, a prawda jest taka, że wszyscy mamy swoją godność i jesteśmy wartościowi” (A); „Godność to zdecydowanie wartość, którą warto mieć. Jest to trudne w obecnych realiach życia, kiedy dookoła czyha 
tyle pokus niezwiązanych z wartościami, ale z szybkimi pieniędzmi, układami, niezdrowymi zależnościami” (A); „Uzasadnienie uznania godności ludzkiej za wartość może być takie, że jest to coś, co nie wszyscy mogą posiadać, bądź posiadać w mniejszym lub w większym stopniu, a problem godności ludzkiej dotyka nas wszystkich. Jako że jest to ważna kwestia, można uznać, że ma swoją wartość i jest pożądana w społeczeństwie” $(\mathrm{O})$; „Jest ogromną zaletą, uważam, że każdy człowiek ją posiada, jednak stopniowo ona zanika, lub wręcz przeciwnie, rozrasta się. Wszystko zależy od człowieka i jego postępowania. Trzeba znać swoją wartość. Jakaś forma doskonałości” (O); „Jest to jedna z ważnych cech, której często nie dostrzegamy, a zapominamy, że tacy ludzie powinni być wzorem dla innych" $(\mathrm{O})$.

\section{Uwagi końcowe}

W uzasadnianiu godności osoby będącej niezbywalną wartością ludzkiego życia odnosimy się zarówno do przesłanek filozoficznych przemawiających nie tylko do ludzi wierzących, ale i do wszystkich ludzi, jak i do przesłanek teologicznych związanych $\mathrm{z}$ wiarą $\mathrm{w}$ dziecięctwo Boże człowieka. Obydwa te aspekty nie powinny być sobie przeciwstawiane, nawet jeżeli pierwsza argumentacja (etyka humanistyczna) ukierunkowuje się na zewnątrz do świata, druga (teologia) - niejako do środka, do członków Kościołów chrześcijańskich lub ludzi wierzących w Boga. Są to tylko dwie perspektywy patrzenia na tę samą prawdę o godności i wielkości człowieka. W rzeczywistości ludzie odwołują się jeszcze do argumentów wywodzących się z różnych przekonań moralnych, a niekiedy nawet do przesłanek utylitarno-pragmatycznych.

Po przeprowadzeniu w miarę dokładnych analiz empirycznych ustaliliśmy następującą częstotliwość podawanych uzasadnień godności ludzkiej: a) godność ludzka jako gwarancja i przejaw życia moralnego (22,4\% ogółu badanych osób); b) godność uzasadniana przez inne wartości (15,8\%); c) godność jako człowieczeństwo (9,7\%); d) godność jako coś danego, nieutracalnego (7,9\%); e) godność jako wartość szczególnie ważna (7,9\%); f) godność jako wartość teologiczna (7,9\%); g) godność jako wartość wychowawcza (3,6\%); h) godność jako coś, czego się nie przestrzega $(3,0 \%)$; i) godność jako cecha odróżniająca człowieka od innych bytów (2,4\%); inne wypowiedzi $(2,4 \%)$ - „Godność ludzka jest wartością subiektywną, każdy posiada własną definicję tego pojęcia. Uzasadnić możemy ją potrzebami, które odczuwamy”; „Uznanie godności ludzkiej jest sprawą indywidualną i nie ma ona jednolitej definicji”.

W całej zbiorowości młodzieży 13,9\% ankietowanych zrezygnowało z udzielenia odpowiedzi lub przyznawało się do niewiedzy („Nie wiem”; „Nie zastanawiałem się”; „Trudno powiedzieć”; „Godność ludzka na pewno jest uznawana 
za wartość, ale jak ją uzasadnić, to nie mam pojęcia”; „Godność to wartość, której nie da się jej określić”); 3,1\% badanych udzieliło odpowiedzi negatywnych („Godności ludzkiej osobiście nie uznaję za wartość, ponieważ dla mnie jest ważniejsza wierność niż postawa drugiej osoby. Wiele razy spotkałem się z osobami, o których myślałem w ten sposób, iż posiadają jakąś godność, lecz po spędzeniu czasu z nimi stwierdzam, że jednak nie można uznać tego za wartość, tylko jako dodatek” (A); „Nie uznaję, że godność człowieka to wartość. Nie można ocenić żadną miarą wartości ludzkiej moralności. Dobro i zło jest względne” (S); „Godność ludzka nie jest wartością, ponieważ wielu ludzi jej nie posiada, mało ludzi posiada godność, a niektórzy w ogóle nie mają o niej pojęcia” (A); „Była być może wartością, chociaż aktualnie chyba odchodząca do lamusa" (P).

Mimo że zdecydowana większość osób biorących udział w badaniu empirycznym udzieliła jakichś - mniej lub bardziej trafnych - odpowiedzi, to aż prawie co trzeci ankietowany zaznaczył, że problematyką godnościową w ogóle nie zajmował się w swoim życiu lub tylko sporadycznie albo bardzo rzadko $(30,0 \%)$. Można przypuszczać, że godność w ich życiu jest wartością, którą wprost nie dostrzega się lub wyczuwa tylko intuicyjnie. Nie można jej określić za pomocą ścisłej, logicznej definicji. Nie ma ona nic lub ma niewiele wspólnego z obiektywną strukturą ludzkiego bytu. Odrzucenie czy niedostrzeganie teologicznych i filozoficznych uzasadnień godności ludzkiej sprawia, że sama idea staje się zmienna i przypadkowa, do pewnego stopnia deklarowana, a nawet poniekąd „niewidzialna”.

Znaczna część młodzieży nie odwołuje się do godności jako podstawy pochwały lub nagany różnych działań ludzkich, a w deklarowanych uzasadnieniach zadowala się szlachetnymi skądinąd apelami i niewiele znaczącą retoryką lub swoistym aktem afirmacji. Nieumiejętność sformułowania zasadnych argumentów za godnością jest zastępowana odwoływaniem się wprost lub pośrednio do zjawiska naruszania godności. Godność jest dla zdecydowanej godności badanej młodzieży wartością, dostrzeganą i doświadczaną, ale mniej się nad nią reflektuje. Trudno o niej mówić, a tym bardziej ją logicznie uzasadnić. W rzeczywistości jest ona realizowana na różne sposoby, poprzez autonomiczne decyzje i wybory.

Ogólnie można powiedzieć, że większość respondentów myśli o godności w sposób pozytywny, choć dość często niepogłębiony, i wiąże z nią różnorodne treści. Zdają sobie oni sprawę z tego, że godność jest bardzo ważną wartością, której człowiekowi nie można zabrać, że jest dana po to, aby darzyć szacunkiem człowieka (siebie i innych), że stanowi najwyższą i nieutracalną wartość ludzkiego bytu. Pojęcie godności jest na ogół nasycone skojarzeniami emocjonalnymi o zasadniczo pozytywnym charakterze, ale odnosi się do różnych aspektów i obszarów wartościowania rzeczywistości. Młodzież wskazuje raczej na indywidualne i społeczne funkcje godności niż na jej istotę, częściej 
na indywidualne niż społeczne wymiary godności. W polu widzenia badanej młodzieży nie pojawia się (lub tylko sporadycznie) związek godności z religią (uzasadnienia teologiczne).

\section{Bibliografia}

Adamski F., Poza kryzysem tożsamości, w kierunku pedagogiki personalistycznej, w: Poza kryzysem tożsamości, w kierunku pedagogiki personalistycznej, red. F. Adamski, Kraków 1993, s. 9-15.

Biesaga T., Podstawy etyki i bioetyki, Kraków 2016.

Bronk A., Kategoria godności człowieka „Annales Universitatis Curie-Skłodowska. Sectio I. Philosophia - Sociologia" 2010, nr 1(35), s. 77-96.

Chymuk M., Aksjologiczne preferencje studentów uczelni krakowskich, Kraków 2004.

Dylus A., Godność człowieka: fundament wartości europejskich, „Teologia i Człowiek” 2004, nr 3, S. 9-18.

Fel S., Jan Paweł Il a prawa człowieka, w: De revolutionibus orbium populorum Joannis Pauli II. Papież wobec wykluczenia społecznego, red. K. Pilarczyk, G. Sokołowski, Warszawa 2015, s. 107-137.

Fel S., Społeczna gospodarka rynkowa w społecznej nauce Kościoła katolickiego, w: Socjologia ekonomiczna, red. W. Morawski, Warszawa 2018, s. 158-164.

Gajda J., Wartości w życiu i edukacji człowieka, Toruń 2013.

Granat W., Godność człowieka i jej współczesne uzasadnienia, w Aby poznać Boga i człowieka. Cz. 2 (O człowieku dziś), red. B. Bejze, Warszawa 1974, s. 223-256.

Hodgkiss P., A moral vision: human dignity in the eyes of the founders of sociology „,The Sociological Review" 2013, nr 3(61), s. 417-439.

Jan Paweł II, Pamięć i tożsamość. Rozmowy na przełomie tysiącleci, Kraków 2005.

Kanclerz B., Orientacje życiowe młodzieży akademickiej, Poznań 2015.

Lekka-Kowalik A., Godność podmiotów edukacji, w: Encyklopedia aksjologii pedagogicznej, red. K. Chałas, A. Maj, Radom 2016, s. 383-387.

Majka J., Etyka społeczna i polityczna, Warszawa 1993.

Mazurek F.J., Wartości akceptowane w Unii Europejskiej, "Summarium”1999-2000, nr 28-29, s. 11-37.

Mazurek F.J., Katolicka nauka społeczna - status metodologiczny i główne obszary problemowe, w: Katolicka nauka społeczna. Podstawowe zagadnienia z życia społecznego i politycznego, red. S. Fel, J. Kupny, Katowice 2007, s. 11-30.

Ossowska M., O człowieku, moralności i nauce, Warszawa 1983.

Piluś H., Godność osobowa jako podstawa i uzasadnienie niezbywalnych praw i wolności człowieka, w: Prawa i wolności człowieka w edukacji demokratycznego państwa. Materiały I Ogólnopolskiej Konferencji Naukowej Siedlce-Chlewiska 7-8 grudnia 1999 r., red. R. Rosa, Siedlce 1999, s. 71-88.

Piwowarski W., ABC katolickiej nauki społecznej. Część 1 (Wprowadzenie, podstawy, kierunki), Pelplin 1993.

Rynio A., Wychowanie do odpowiedzialności. Studium teorii i praktyki pedagogiki integralnej, Lublin 2019.

Wyszyński S., Kimże jest człowiek..., opr. Instytut Prymasowski Ślubów Narodu, Warszawa 1987.

Stępień K., Godność osobowa, w: Encyklopedia aksjologii pedagogicznej, red. K. Chałas, A. Maj, Radom 2016, s. 376-383.

Vidal M., Absolutna wartość osoby miejscem spotkania i zespolenia etyki świeckiej z moralnościq religijną, tłum. L. Balter, w: Moralność chrześcijańska, red. L. Balter, K. Czulak, P. Góralczyk, S. Stancel, Poznań-Warszawa 1987, s. 125-147.

Wojtyła K., Kazanie na Areopagu. 13 katechez, red. M. Wolańczyk, Kraków 2018. 


\section{Godność ludzka jako wartość i sposoby jej uzasadniania w opinii młodzieży}

\section{Streszczenie}

Uzasadnienie godności ludzkiej przebiega na płaszczyźnie przyrodzonej (filozoficznej) i nadprzyrodzonej (teologicznej) lub intuicyjnej. W artykule dokonano analizy i interpretacji wypowiedzi młodzieży szkolnej i akademickiej dotyczących uznawanych przez nią uzasadnień godności. Zostały ustalone następujące kategorie uzasadnień: a) godność ludzka jako gwarancja i przejaw życia moralnego (22,4\% ogółu badanych osób); b) godność uzasadniana przez inne wartości (15,8\%); c) godność jako człowieczeństwo $(9,7 \%)$; d) godność jako coś danego, nieutracalnego (7,9\%); e) godność jako wartość szczególnie ważna (7,9\%); f) godność jako wartość teologiczna (7,9\%); g) godność jako wartość wychowawcza (3,6\%); h) godność jako coś, czego się nie przestrzega (3,0\%); i) godność jako cecha odróżniająca człowieka od innych bytów $(2,4 \%)$; inne wypowiedzi $(2,4 \%)$. W całej zbiorowości młodzieży 13,9\% ankietowanych zrezygnowało z udzielenia odpowiedzi, a 3,1\% udzieliło odpowiedzi negatywnych. Większość ankietowanej młodzieży myśli o godności pozytywnie, choć dość często $\mathrm{w}$ niepogłębiony sposób, i wiąże z nią różnorodne treści. Uzasadnienia teologiczne pojawiają się dość sporadycznie.

Słowa kluczowe: godność osobowa, godność jako wartość, uzasadnienia godności, młodzież szkolna i akademicka

\section{Human dignity as a value and the means by which it can be justified in the opinion of youth}

\section{Summary}

The justification of human dignity occurs on the natural (philosophical) and supernatural (theological) or intuitive levels. The article analyzes and interprets high school and university students' statements regarding the justifications of dignity recognised by them. The following categories of justifications were identified: a) human dignity as a guarantee and manifestation of moral life (22.4\% of the total number of people surveyed); b) dignity justified by other values (15.8\%); c) dignity as humanity $(9.7 \%)$; d) dignity as something given and indelible (7.9\%); e) dignity as a particularly important value $(7.9 \%)$; $\mathrm{f}$ dignity as a theological value $(7.9 \%)$; g) dignity as an educational value (3.6\%); h) dignity as something that is not respected (3.0\%); i) dignity as a feature that distinguishes human beings from other beings (2.4\%); other statements (2.4\%). In the whole group of youth, $13.9 \%$ of the respondents decided not to give any answer and 3.1\% gave negative answers. Most of the surveyed young people think positively about dignity, however, often in a rather shallow way, connecting it with various contents. Theological justifications come up quite rarely.

Key words: personal dignity, dignity as a value, justification of dignity, high school and university youth 